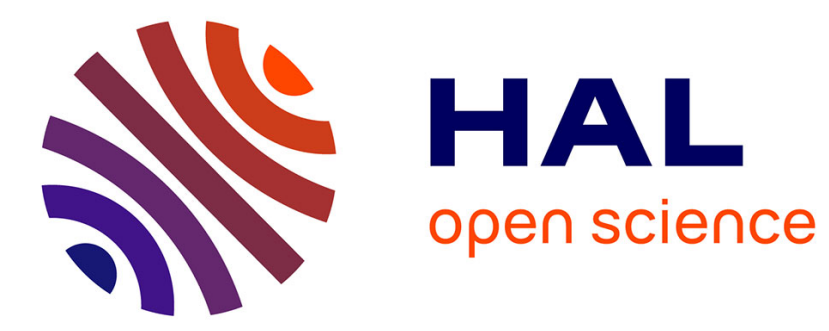

\title{
Trillion dollar streets
}

César A. Hidalgo

\section{To cite this version:}

César A. Hidalgo. Trillion dollar streets. Environment and Planning B: Urban Analytics and City Science, 2020, 47, pp.1133 - 1135. 10.1177/2399808320949295 . hal-03058643

\section{HAL Id: hal-03058643 https://hal.science/hal-03058643}

Submitted on 4 Mar 2021

HAL is a multi-disciplinary open access archive for the deposit and dissemination of scientific research documents, whether they are published or not. The documents may come from teaching and research institutions in France or abroad, or from public or private research centers.
L'archive ouverte pluridisciplinaire HAL, est destinée au dépôt et à la diffusion de documents scientifiques de niveau recherche, publiés ou non, émanant des établissements d'enseignement et de recherche français ou étrangers, des laboratoires publics ou privés. 


\section{Trillion dollar streets}

\section{César A Hidalgo}

Artificial and Natural Intelligence Toulouse Institute (ANITI), France;

University of Toulouse, Alliance Manchester Business School, University

of Manchester, UK; School of Engineering and Applied Sciences,

Harvard University, USA
EPB: Urban Analytics and City Science $0(0) \mathrm{I}-3$

(C) The Author(s) 2020

Article reuse guidelines: sagepub.com/journals-permissions DOI: $10.1177 / 2399808320949295$ journals.sagepub.com/home/epb

Cities are islands of private property connected by public space. But even though public space represents a substantial amount of a city's surface, its uses are limited mostly to the circulation of cars.

Forty-nine percent of the land in Manhattan is public, not because Central Park is big, but because streets represent $36 \%$ of the island. That means that in Manhattan alone more than $\$ 500$ billion worth of land is dedicated almost exclusively to cars (Bloomberg.com, 2018).

Of course, streets are necessary. But our current allocation of public space may be far from optimal. In the US, trillions of dollars of land in prime locations are dedicated to streets and parking spots. But it doesn't have to be this way. Compare Tokyo to New York. The Asian mega city dedicates only $29 \%$ of its surface area to streets. This 7 percentagepoints difference is due in part to Tokyo's restriction on on-street parking.

Covid did not evolve to change our cities, but is certainly giving us an opportunity to do so. One place where the disease has put enormous pressure is on the excessive allocation of public spaces to cars. Cities across the world have closed hundreds of miles of roads in an effort to open streets to their residents (Streetsblog USA, 2020). But to reduce the spatial footprint of cars, cities will need more than goodwill and orange cones. They will need to solve supply side and demand side problems.

On the supply side, public transportation is the obvious substitute to private vehicles (although they do not solve the problem of package delivery). But for a change, I would like to focus on the demand side of the problem.

The demand side question is: who wants to keep cars out of the streets and actually has the power to do so? Here the obvious solutions are to increase the space dedicated to bicycles, sidewalks, and cafes (Manjoo, 2020). But once we consider the land value of streets, more radical alternatives come into play.

\footnotetext{
Corresponding author:

César A. Hidalgo, ANITI, University of Toulouse, 4I Allée Jules Guesde, 31000 Toulouse, France.

Email: esar_hidalgo@fas.harvard.edu
} 
Consider a single segment of 57 street in New York (let's say between 5th and 6th avenues). This is $\sim 6000$ square meters (1.48 acres) of land in Midtown Manhattan. The land alone is worth hundreds of millions of dollars, but transforming that single street segment into parks and a single skyscraper (occupying $20 \%$ of the street), would result in billions in new property. ${ }^{1}$ That's millions of dollars in new tax revenue for the city and hundreds of new residential and commercial units.

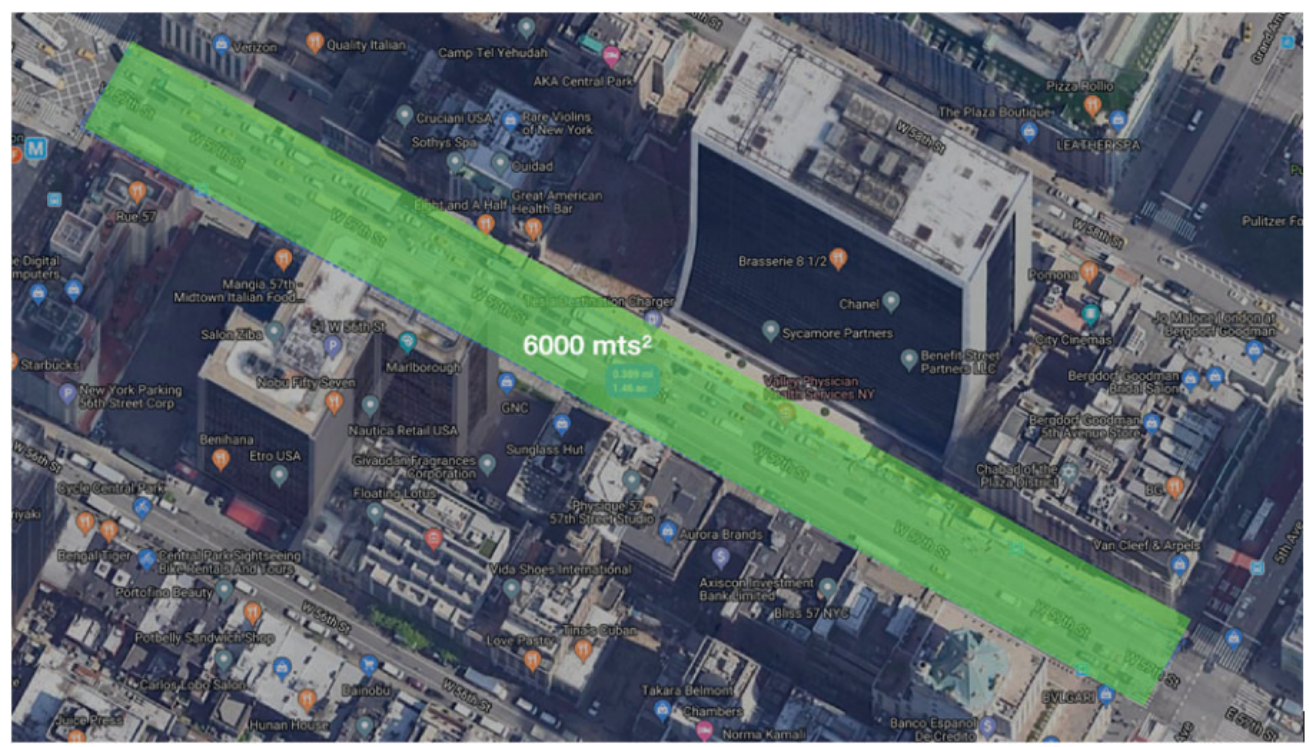

Of course, this idea seems far-fetched. We are now in a depressed economy with people retreating from cities. But the agglomeration forces that gave rise to megacities will not vanish with the pandemic (Balland et al., 2020; Diodato et al., 2018; Ellison et al., 2010; Mulligan, 1984). Before the pandemic began, traffic in midtown Manhattan was not much faster than walking (5 to $7 \mathrm{mph}$ ) (Manjoo, 2020). It is hard to justify streets with such low transportation efficiency. The demand for real estate will return, and when it does, the lobby of developers may be more powerful than that of Detroit.

If you accept the idea that some streets should evolve into parks and buildings, the question is then how to do it responsibly. Transforming 1\% of Manhattan's streets into real estate is an enormous market opportunity, but it is one that will not self-regulate. It will require thinking carefully about the use of this opportunity to create mix used neighborhoods that accommodate people from diverse incomes and backgrounds. It will require thinking how to use the new real estate tax revenue in ways that support these communities, with added transportation, health, and education services.

Opportunities are fleeting. Covid is giving us a chance to rethink everything. It is up to us, to think creatively and explore new ideas as best as we can.

\section{Declaration of conflicting interests}

The author(s) declared no potential conflicts of interest with respect to the research, authorship, and/or publication of this article. 


\section{Funding}

The author(s) disclosed receipt of the following financial support for the research, authorship, and/or publication of this article: The author acknowledges support from the ANITI Chair at the University of Toulouse.

\section{Note}

1. 50,000 square meters or real state in midtown Manhattan are worth about a billion dollars. ${ }^{1}$ For reference, Trump tower has nearly 90,000 square meters.

\section{References}

Balland P-A, et al. (2020) Complex economic activities concentrate in large cities. Nature Human Behaviour 1-7. doi:10.1038/s41562-019-0803-3.

Florida (2018) What's Manhattan's land worth? Try 'Canada's Entire GDP'. Available at: www. bloomberg.com/news/articles/2018-04-24/manhattan-s-land-value-is-an-incredible-1-74-trillion (accessed 30 July 2020).

Diodato D, Neffke F and O'Clery N (2018) Why do industries coagglomerate? How Marshallian externalities differ by industry and have evolved over time. Journal of Urban Economics 106: 1-26.

Ellison G, Glaeser EL and Kerr WR (2010) What causes industry agglomeration? Evidence from coagglomeration patterns. American Economic Review 100: 1195-1213.

Manjoo F (2020) Opinion | I've seen a future without cars, and it's amazing. The New York Times. https://www.nytimes.com/2020/07/09/opinion/sunday/ban-cars-manhattan-cities.html

Mulligan GF (1984) Agglomeration and central place theory: A review of the literature. International Regional Science Review 9: 1-42.

Streetsblog USA (2020) Op-Ed: Here are some cities getting open streets right. Available at: https:// usa.streetsblog.org/2020/05/01/op-ed-heres-some-cities-getting-open-streets-right/ (accessed 30 July 2020).

César A Hidalgo holds a chair at the Artificial and Natural Intelligence Toulouse Institute (ANITI) and is also a faculty at Harvard University and the University of Manchester. Prior to moving to Toulouse, he led the Collective Learning group at MIT. 